\title{
Political Regimes, Path Dependence, and the South Korean Welfare State
}

\author{
SEIL OH \\ School of Public Administration, National Institute of Development Administration \\ 118 Moo3, Serithai Road, Klong-Chan, Bangkapi, Bangkok, THAILAND 10240 \\ E-mail: seilohosi@gmail.com
}

Received: Aug. 11, 2020 Accepted: Aug. 28, 2020 Online published: Sep. 9, 2020

doi:10.5296/jpag.v10i3.17514ＵRL: https://doi.org/10.5296/jpag.v10i3.17514

\begin{abstract}
Contrary to common belief that political actors can fundamentally shape the welfare state, any political regimes with distinct positions on welfare policies are usually put under public scrutiny, which makes it risky for them to simply follow their traditional beliefs without taking into account public reactions over welfare-related decision making. In terms of the welfare state development, South Korea is an interesting example in the sense that parties from different political backgrounds have had the opportunity to run the country for almost the same amount of time, since progressives came to power for the first time in modern Korean history. Based on data ranging from 1998 to 2016, the relationship between the welfare state and political/socioeconomic conditions is evaluated alongside policy implications, revealing the path dependence of the South Korean welfare development. The increase in social spending in South Korea was rather due to natural phenomena such as population aging, than any political actors' approaches to the welfare state.
\end{abstract}

Keywords: welfare state, South Korea, political actors, path dependence, social spending, population aging

\section{Introduction}

South Korea is no exception to the fact that political actors are believed to have fundamental control of the welfare state development. For any kinds of welfare-related problems, blame is usually shifted to political actors, especially parties or regimes in power, sometimes making it difficult for them to win elections, also leaving them no other choice but to come up with solutions, or at least a pro-welfare rhetoric. Some remarks made by sitting presidents or presidential candidates from even conservative parties, such as "Korea is now a welfare 
state" ${ }^{1}$ or "welfare should be expanded without raising taxes", moments with regard to political argumentation on welfare. ${ }^{3}$ However, in regard to welfare policies, a politician's rhetoric is one thing, but the real development of welfare programs is another.

Unlike in most Western countries, there has been a lack of labor parties and social democratic parties based on fundamental support from the working class in South Korea(Kam, 1989). It has usually been pointed out that the main reason South Korea has been regarded as one of laggards in welfare development might lie in the weak political buildup by the working class(Hong, 1999). the parties actually rely on a strong regional base, with few organizational ties with labor(Haggard \& Kaufman, 2008), which could at least partly explain why welfare issues have often been ignored on many occasions in the past where they deserved much more attention from the public than they actually received. The question of "which regional part of the country is a politician from?" has always had to be answered first, prior to questions about his or her political beliefs, including those about welfare policies.

However, even with such a powerful regional orientation of politics(Haggard \& Kaufman, 2008), it is undeniable that South Korea's political system consists of two major groups of parties, one of which is conservative, with its roots in previous authoritarian regimes, and the other is progressive, with a background squarely in the pro-democracy movement. This competition between conservative and progressive parties has also started tackling welfare issues, especially since the end of the authoritarian regime. These issues have become closer to being part of the main political debates over time.

This study aims to evaluate the relationship between political actors, especially regimes and the development of the welfare state while also taking into account some political and socioeconomic conditions regarded as having influence on the welfare state, in order to find out whether any political actors or some other conditions played decisive roles in welfare development in South Korea. In terms of this relationship, South Korea could be a good example in the sense that both the progressive side and the conservative side have had the opportunity to run the country for almost the same amount of time from 1998, when progressives came to power for the first time, to 2016, when conservative regime came to the end, almost abruptly.

1 This comment was made by president Lee Myung-bak on December 22, 2010. It is noted that Park-Geun-hye also made similar comments pointing out that her father-Park Chung-hee, the president of South Korea from 1963 to 1979, had a dream of establising a welfare state (Joo, 2014).

2 This was the slogan used by presidential candidate Park Geun-hye, which was made famous during a television debate with another candidate, Moon Jae-in, in 2012.

${ }^{3}$ It is also noted that both sides take a progressive attitude toward welfare state, especially when elections - either presidential or regional — are imminent. 


\section{After the Crisis: Four Regimes From Two Backgrounds, and Welfare}

It was the Asian financial crisis of the late 1990s that pushed welfare issues into the spotlight of society. Given the aftermath of the crisis, including a high unemployment rate and heavily affected labor conditions ${ }^{4}$, "welfare" was no longer an issue that could be simply ignored. This change of situation, however, was still not enough for welfare issues to become the top priority of political parties. Why were the welfare issues not able to gain political attention in South Korea, unlike many Western welfare states where welfare policies almost always fiercely debated in the major political arena? Kang (2013) argues that, under the political context of authoritarian vs. pro-democratic conflicts, "welfare" has been neither an attractive nor an effective topic in terms of winning votes or gaining public support for anti-government protests. Welfare issues have been discussed more in the context of each specific policy area, rather than under consistent approaches towards welfare in general by political parties (Kang, 2013).

It was in the context of recent conservative vs. progressive regimes that welfare issues started to be discussed in a more serious manner. After the arrival of the Kim Dae-jung regime in 1998, South Korea experienced ten years under a pro-democratic administration, after which pro-market conservative parties represented by Lee Myung-bak came to power, arguably reducing the expansion of the welfare state (Powell \& Kim, 2014). During the Lee Myung-bak regime, the heavily debated issues about the so-called "free meals for school children" showed how distinctively different each political party's position was towards welfare policies (Kang, 2013). In addition to the "free meal" case, which was so controversial because of its strong association with education, which thus heavily attracted public attention in South Korea, there have been other seriously discussed topics such as universal vs. targeted welfare and taxation with regard to welfare policies during these politically contrasted regimes since 1998 (Kang, 2013). Having experienced much controversy in relation to welfare, it has become clearer to the public how each party (or regime) takes either a conservative or a progressive approach towards specific welfare policies, given some socioeconomic conditions the parties have faced and their political identities.

The fact that Mr. Kim Dae-jung was able to come to power in 1998 and is regarded as important in welfare development in South Korea is because Kim's regime was the first politically progressive regime with its roots in the pro-democracy movement to promote so-called "productive welfare" as a salient part of its policy design (Hong \& Song, 2006). This has also been reflected in social spending, which rapidly increased under Kim's regime. If focusing on the Kim Dae-jung era alone, it would seem that the more democratic a state is, the more it spends on welfare. It should also be pointed out that statutory welfare

${ }^{4}$ In 1999, the unemployment rate of South Korea reached $8.7 \%$, which was the highest level in modern South Korean history ("The unemployment rate reached 8.7\%.," 1999).

5 When the 2010 regional election was near, the issue of free meals for school children was heavily debated between the progressive party, seeking universal protection (for "all" the school children), and the conservative party, with its targeted approach (for the school children only from the low income households) (Ma, 2012). 
expenditures exceeded non-statutory expenditures for the first time during this regime, which could be regarded as an indicator of the expansion of state welfare (Hong \& Song, 2006). The expansion of the welfare state was exacerbated under the Roh Moo-hyun regime, which finally made welfare policies one of the top priorities of the government in terms of state expenditure. Both of the progressive regimes preferred balanced approaches towards welfare, also taking into account economic growth, rather than forming entirely redistribution-based welfare policies that could have been regarded as too "leftist" or "progressive" by conservative electorates in South Korea.

As one of the most controversial periods of welfare development in South Korea, the welfare policies of the Lee Myung-bak regime have been generally criticized due to the regime's neo-liberal approaches and market-oriented attitudes towards welfare (Joo, 2008; Kim \& Kim, 2012; Kim, 2009). In contrast, President Lee Myung-bak himself famously argued that South Korea has become a welfare state under his regime, pointing out the expansion of the welfare budget designed by his government. Despite his passionate remarks on the welfare state, it should be noted that the welfare state he sought to establish was based not on redistribution but on economic growth. According to the Lee Myung-bak regime, most of the welfare problems could be automatically resolved if some amount-say 7\%-of economic growth were to be accomplished. ${ }^{6}$ Under his pro-market regime with its emphasis on free competition, thus allowing opportunities to compete, rather than on easy access to free meals, welfare policies were not top priorities but just minor issues that could be dealt with once certain economic growth targets were met.

It should be noted that, even though Lee Myung-bak's successor, Park Geun-hye had a politically conservative background, she explicitly emphasized the importance of welfare, even confidently suggesting she might be able to expand welfare, without any related raises in taxes. In relation to her famous slogan, "welfare expansion without raising taxes", which was actually effective in winning the presidential election in 2012, her government has been heavily confronted by opposition parties with doubt on the feasibility of such an approach. Relatedly, the Park Geun-hye regime argued that the taxation needed to finance the expansion of welfare could be realized by the formalization of the informal economy. However, throughout her term, which ended dishonorably earlier than officially expected due to a scandalous event related to Park Geun-hye's improper and hidden relationship with Choi Seo-won ${ }^{7}$, there was hardly any evidence that the expansion of welfare-if there has been any-was financed by the mechanism of the formalization of the informal economy.

\footnotetext{
${ }^{6}$ Presidential candidate Lee Myung-bak's election manifesto was called the "747 manifesto" because the candidate aimed for a 7\% economic growth rate, USD 40,000 GDP per capita, and the 7 th highest rank among economic power states, none of which has been realized under his regime.

${ }^{7}$ Previously known as Ms. Choi Soon-sil.
} 


\section{Ml Macrothink}

Table 1. Political Regimes in South Korea (1998-2016)

\begin{tabular}{cccc}
\hline \multicolumn{2}{c}{ Progressive Regimes } & \multicolumn{2}{c}{ Conservative Regimes } \\
\hline Kim Dae-jung & Roh Moo-hyun & Lee Myung-bak & Park Geun-hye \\
$1998-2002$ & $2003-2007$ & $2008-2012$ & $2013-2016$ \\
\hline
\end{tabular}

In sum, South Korea's welfare development experienced two distinct periods consisting of progressive governments focused on welfare expansion and conservative governments with positions on welfare more or less different from those of previous regimes. However, as figure 1 shows, taking a simple glance at the welfare statistics of social spending as a percentage of GDP does not quite confirm expectations about the welfare development during these two distinct periods.

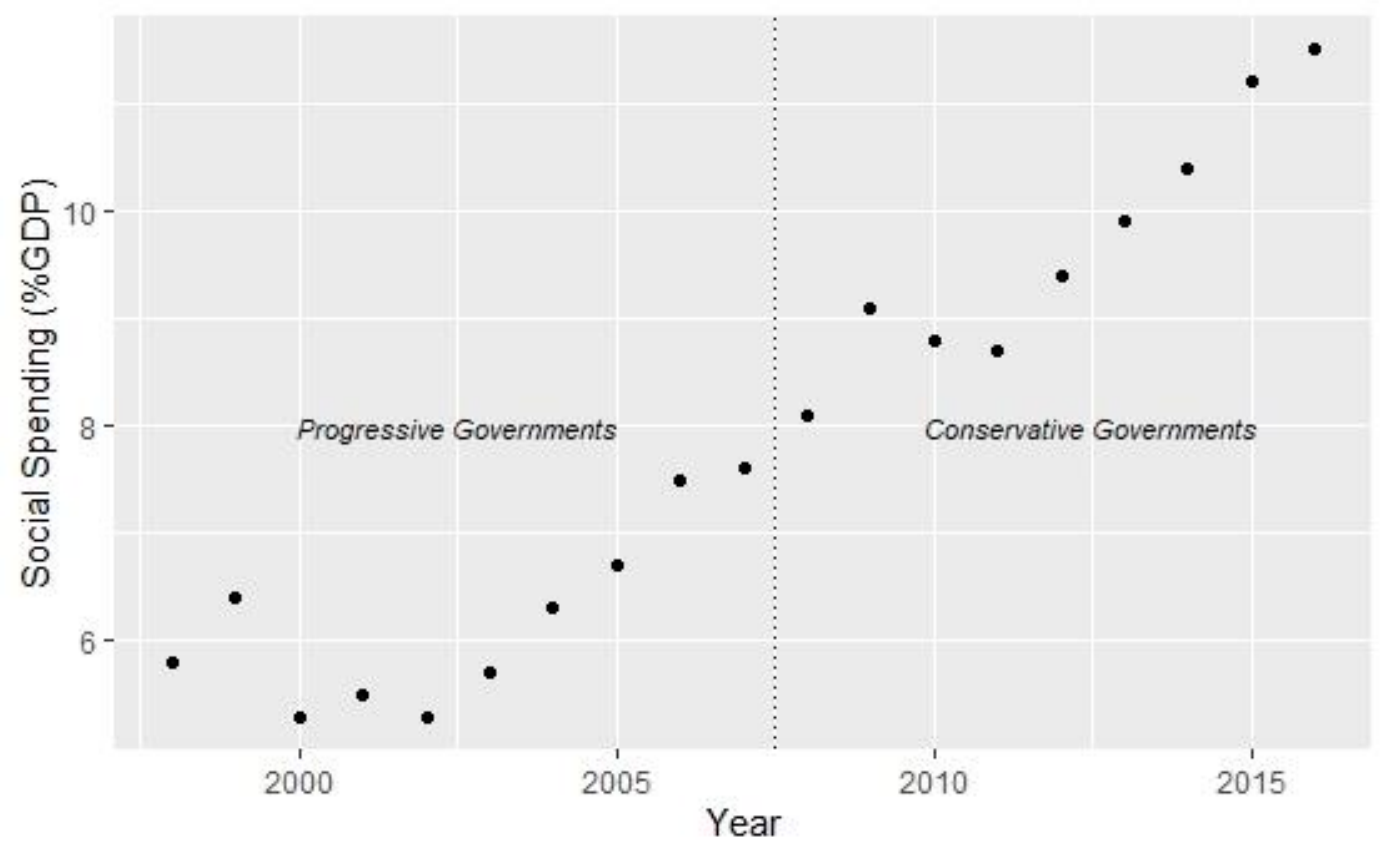

Figure 1. Social Spending as a Percentage of GDP in South Korea, 1998-2016

Source: KOSIS (n.d.)

Figure 1 illustrates that social spending as a percentage of GDP has been generally increasing regardless of the change in regimes in South Korea. Does this mean that the development of welfare has not been significantly affected by each regime's attitude towards welfare? That question is the starting point of this study, as discussed below.

\section{Theoretical Considerations}

In relation to the major determinants of welfare development, actors, especially political ones, have been the usual focus of arguments. It should be noted that in the context of European welfare states, there have been a number of studies suggesting that the political power of social democratic and Christian democratic parties played a crucial role in the expansion of the welfare state (Allan \& Scruggs, 2004; Castles, 1998; Huber \& Stephens, 2001; Ross, 2000). Arguably, a significant partisan effect has been recognized by some studies in the 
context of European countries (Huber \& Stephens, 2001), with the implications that some conditions, such as a strong leftist party and the weakness of the market-oriented party, are favorable conditions for welfare expansion (Castles, 1982, 1998; Schmidt, 2010). For non-European states, the relatively low level of social protection has been the most common issue (Schmidt, 2010). The reason these states remain welfare laggards has been arguably explained by their relatively strong pro-market parties along with other socioeconomic factors (Schmidt, 2010). In regard to what motivates political actors to take any actions, as usually expected, electoral pressures are regarded as an important factor in encouraging politicians to start managing welfare resources (De Schweinitz, 1964; Dornbusch \& Edwards, 1991; Malloy, 1987; Skidmore, 1977) In contrast, there have been arguments that there is "no systematic relationship between regime type and the room politicians have to maneuver'(Brown \& Hunter, 1999, p. 779), and the simple distinction between regime types does not tell the whole story about factors that have potential influence on political behavior (Geddes, 1995; Stephen Haggard \& Kaufman, 1992, 1995; Nelson, Joan M., 1990; Przeworski \& Limongi, 1993; Remmer, 1986, 1990). Regardless of whether it is about regimes or politicians, there has been awareness that political actors can shape or reshape the welfare state, given socioeconomic conditions they face. However, beyond the actor-focused framework, there have been emerging arguments about path dependence of the welfare state. To them, it is not welfare state expansion or retrenchment initiated by political actors that matters, but the resilience of the welfare state. The welfare state, once established, has not been one any political actors could fundamentally reshape or even dismantle (Pierson, 1994), the path dependence theorists argues.

\subsection{Actor-Focused Theory}

Conventional welfare state theory has been focused on what kind of actors play a crucial role in welfare state expansions. Pointing out that parties are major determinants of welfare development, actor-focused theorists argue that people should be regarded as consumers in a market of welfare policies (F. G. Castles, 1982; Hibbs, 1977; Huber \& Stephens, 2001; Schmidt, 2010). The social spending as a percentage of GDP and the party composition of governments are usually measured as indicators in welfare evaluation (Schmidt, 2010). A party that has a large majority in a government and faces fewer veto players has more political impact on the welfare state (Schmidt, 2010). Some actor-focused theorists argue that today's parties are different from previous parties with distinct policy positions, increasingly taking converging attitudes, especially towards the welfare state (Schmidt, 2010; Seeleib-Kaiser, van Dyk, \& Roggenkamp, 2008), pointing out that explaining all welfare state issues with traditional party positions would not be meaningful or even possible. Actor-focused theorists criticized each other, however, within the analytical framework of actors.

Also recognizing the importance of political institutions, Tsebelis (1995) argues that if any legislation is to be passed, there should be agreement from veto players. Veto players consist of partisan - if they are political parties — or institutional decision-makers, if they are just any institutions with potential control over the enactment or implementation of a policy. In regard to the association between the welfare state and partisan veto players, the issue of "which 
party seizes power" is one of the main topics of actor-focused theories, since the attitude towards welfare state has been one of the criteria for categorizing political parties as either conservative or progressive.

As a theory widening the spectrum of actors and potential determinants, another actor-focused theory brought about two arguments, one of which is that the states play an active role in realizing their political beliefs in terms of social spending (supply side), and the other is that the socioeconomic and non-supply side conditions affect the level of social spending while making it necessary for the governments to adjust their welfare policies in accordance with those conditions (demand side) (Buracom, 2011). This theory, however, was not able to break free from the traditional framework of actor-based argument, either.

\subsection{Path Dependence Theory}

Based on the scope of analysis different from conventional actor-focused theory illustrated above, path dependence theorists, pointing out the importance of context, relationship, and power structure of the welfare states rather than actors, argue that well-established welfare states cannot be easily dismantled even under very hawkish conservative politicians such as Thatcher and Reagan (Pierson, 1994). ${ }^{8}$ Whenever conservative regimes seek retrenchment to abide by their political beliefs in terms of welfare state, they usually risk losing votes in elections. Voters are more sensitive to losing what they already have than to gaining something they did not have before (Pierson, 1994). Therefore, retrenchment advocates hesitate to put their beliefs to practice in a visible way, which is the reason Pierson (1994) points out the possibility of systemic retrenchment such as defunding, policy-induced changes in public opinion, the modification of political institutions, and the weakening of pro-welfare state interest groups, the attempts of which are not always successful. As a starting point of the theory of welfare resilience and as a milestone in the history of welfare studies, Pierson $(1994,1996,1998)$ raised the issue of the path dependent nature of the welfare state, establishing a theoretical framework for further studies of welfare development throughout the world (Bonoli, 2007; Korpi, 2006; Weaver, 2010).

Even with all the pressures that most OECD (the Organization for Economic Co-operation and Development) governments have been under, political support has usually been "deep reservoirs" (Pierson, 1998) for the welfare policies. There has not been an incidence in any country where the retrenchment effort has successfully been able to gain majority support from the public. Pierson (1998) even argues that any attempts to dismantle the welfare state in a clear and direct way can be suicidal in a political sense. ${ }^{9}$ There are two main

${ }^{8}$ Pierson (1994) explains the conception of path dependence with the example of the dominance of the QWERTY keyboard design. There has been no scientific evidence that the QWERTY design is superior to other kinds of design. People use the QWERTY design simply because they have always used the same design. There has been no other reason.

${ }^{9}$ However, even after confirming that there is hardly any evidence of meaningful curtailment of welfare expenditure in Britain, Germany, Sweden, or the United States from 1974 to 1990, which is usually regarded as a period of austerity, Pierson (1996) hesitates to come to the conclusion with a quantitative analysis that there has been no retrenchment in these welfare 
assumptions in the study of path dependence, indicating, first, that the welfare states remain stable despite political actors' intention to dismantle them, and second, political actors play mostly an ineffective role in reshaping the welfare states. ${ }^{10}$

\section{The Model Specification}

To find out which welfare state theory from above can give best possible explanation of South Korea, the conventional actor-focused model should be put to test in the context of South Korea. Did political actors (here governments) play a significant role in the welfare state development in South Korea? Who was the main driver of the South Korean welfare state, if political actors had only insignificant impact on the welfare state development?

\begin{tabular}{|c|c|c|c|}
\hline & & Political Prog & of Government \\
\hline & & Low & high \\
\hline & & Low social spending & Moderate social spending \\
\hline & & $\downarrow$ & $\downarrow$ \\
\hline & Low & High income inequality & Moderate income inequality \\
\hline Socioeconomic & & $\downarrow$ & $\downarrow$ \\
\hline Conditions & & High poverty rate & Moderate poverty rate \\
\hline Favorable & & Moderate social spending & High social spending \\
\hline Welfare State & & $\downarrow$ & $\downarrow$ \\
\hline & High & Moderate income inequality & Low income inequality \\
\hline & & $\downarrow$ & $\downarrow$ \\
\hline & & Moderate poverty rate & Low poverty rate \\
\hline
\end{tabular}

Figure 2. The Conceptual Framework: Political Progressivism of Government, Socioeconomic Conditions, Social Spending, Income Inequality, and Poverty Rate

Under the Actor-focused model, the hypothetical relationship between the political progressivism of governments and socioeconomic conditions can be conceptualized as above. As the conceptual framework illustrates, it is expected that the more progressive a government is, the higher the social spending will be, resulting in low income inequality and a low poverty rate, which will be further exacerbated as the socioeconomic conditions become more favorable towards the welfare state. This conceptual framework can be put to test in the context of South Korea, where the two major political parties with distinctively different levels of progressivism (or conservatism) both had a chance to run the state for almost the same length of time, to reveal whether South Korea's welfare development can be explained by conventional actor-focused theory. If political actors had insignificant effect on the South Korean welfare state, regardless of socioeconomic conditions they were under, only confirming the resilience of the welfare state, path dependence theory can be an alternative to

states, due to the possibility of "lagged cutbacks that do not show up in spending figures" (Pierson, 1996, p. 159).

${ }^{10}$ Path dependence studies are likely to be under criticisms that they just reinvent the wheels, and often denied publication, given that the "scholarly incentives promote hunting for social policy change"(Pierson, 2011). 
actor-focused theory to explain the South Korean welfare state.

The first part of the analysis reveals some factors with significant differences between progressive and conservative regimes. In an ANOVA (analysis of variance) test, among some variables with potential influences on the welfare state, only those showing statistical significance in accordance with each group of political regimes are put into the regression equation for the second part of the analysis. Given the limited number of samples from the period covering less than twenty years ${ }^{11}$, it is important to focus on variables with significant differences between both groups of political regimes rather than to take into account every possible variable with some potential influence on the welfare state. ANOVA is one of the best methods for selecting meaningful variables from a number of variables.

Through ANOVA, first, it is examined whether there has been significant difference in social spending, income inequality and poverty between both groups of political regimes; among these factors, any variables found to be of significant difference from each other are regarded as dependent variables for the second stage analysis. Second, it is also examined whether there has been significant difference in some other variables with potential influence on the welfare state, such as partisanship of the parliament, union membership, political freedom, GDP growth rate, trade openness, unemployment rate, and population aging, between the two groups of political regimes ${ }^{12}$; among these factors, any variables found to be of significant difference are regarded as independent variables for the second stage analysis.

The second stage analysis is designed to examine the association between variables found to be of significant difference between two groups of political regimes. Through multiple regression analysis ${ }^{13}$, the extent to which each independent variable affects the dependent variables is estimated. Third, quantitative results are used to understand what actually happened to the South Korean welfare state during the period dominated by these two

11 Even though there is no minimum sample size for ANOVA, using small number of samples has always the potential danger of bringing about unreliable statistical power to accept or reject hypotheses. To avoid misinterpretations of statistical results, it is very important to examine each scatterplot of 18 years- time-series data carefully, which, thanks to small number of samples in this study, enables the statistical analysis to be confirmed.

12 Most of these variables are the ones usually analyzed by actor-focused theorists, especially,those taking attention not just to acotors, but also to "demand side" variables (e.g. Buracom, 2011).

13 From strictly statistical point of view, there can be two potential criticisms in relation to the methods adopted in this study. One is the issue of small number of samples illustrated above (also see the study using small number of samples such as Buracom, 2011), and the other is related to the issue of applying time series data to regression analysis, given the possibility of having variables with high R-square, but little significance in reality. However, the huge correlation of population aging with social spending definitely shows path dependence of the Korean welfare state in terms of politics and other conditions, which can be confirmed with no difficulty, even with the small number of samples. However, these potential criticisms should be considered seriously, in case no definite impact of some variables is easily recognized. 
different groups of political regimes.

The aims of the research are, first, to reveal any significant association between political actors with socio-economic conditions and the welfare state and, second, to test whether there have been any path dependence throughout the period under two groups of political regimes with different approaches to the welfare state in South Korea.

From the specifications of the dependent and independent variables in the table, regression equations can be formulated as follows:

(In the case that all the variables are regarded as significantly different between the two groups of political regimes by ANOVA test)

Social spending (or income inequality, poverty rate) $=a+b 1$ Partisanship of the government + b2Partisanship of the parliament + b3Union membership + b4Political freedom + b5GDP growth rate + b6Trade openness + b7Unemployment rate + b8Population aging $+Q$

Table 2. Variables and Measurement

Dependent and Independent Variables Applied to Explaining Social Spending in South Korea

\begin{tabular}{|c|c|c|c|}
\hline Variable & Expect sign & Measurement & Data source \\
\hline \multicolumn{4}{|l|}{ Dependent variables } \\
\hline Social spending & n.a. & $\begin{array}{l}\text { Social Spending as a percentage } \\
\text { of GDP }\end{array}$ & KOSIS \\
\hline Income Inequality & n.a. & $\begin{array}{l}\text { Gini coefficient of households } \\
\text { with two or more members living } \\
\text { in cities }\end{array}$ & KOSIS \\
\hline Poverty Rate & n.a. & $\begin{array}{l}\text { Ratio of households with two or } \\
\text { more members living in cities } \\
\text { earning } 50 \% \text { of the median } \\
\text { income or less }\end{array}$ & KOSIS \\
\hline \multicolumn{4}{|l|}{ Independent variables } \\
\hline \multicolumn{4}{|l|}{ Political variables } \\
\hline Partisanship of the government & $\begin{array}{l}+ \\
-\end{array}$ & $\begin{array}{l}\text { Progressive (Dummy 1) } \\
\text { Conservative (Dummy 0) }\end{array}$ & \\
\hline Partisanship of the parliament & + & $\begin{array}{l}\text { Proportion of MPs from a major } \\
\text { progressive party }\end{array}$ & $\begin{array}{l}\text { National } \\
\text { Assembly }\end{array}$ \\
\hline Union membership & + & $\begin{array}{l}\text { Percentage of salary workers } \\
\text { organized into unions }\end{array}$ & KOSIS \\
\hline Political freedom & + & $\begin{array}{l}\text { Each year's scores on the } \\
\text { political freedom of South Korea }\end{array}$ & $\begin{array}{l}\text { Freedom } \\
\text { House }\end{array}$ \\
\hline \multicolumn{4}{|l|}{ Socio-economic variables } \\
\hline GDP growth rate & + & $\begin{array}{l}\text { Annual percentage of GDP } \\
\text { growth }\end{array}$ & World Bank \\
\hline Trade openness & + & Ratio of trade to GDP & KOSIS \\
\hline Unemployment rate & + & $\begin{array}{l}\text { Annual percentage of } \\
\text { unemployment }\end{array}$ & MOEL \\
\hline Population aging & + & $\begin{array}{l}\text { Percentage of the population } \\
\text { more than } 60 \text { years old }\end{array}$ & KOSIS \\
\hline
\end{tabular}


In relation to the issues of measuring welfare expansion with social spending (dependent variable), there have been some criticisms, pointing out that measures of social spending cannot provide proper evaluation of welfare state development (Castles, 2002; Esping-Andersen, 1990; Pierson, 1994). However, contrary to the alternative measures other than social expenditure, such as the decommodification index, which is not usually available, the measures of social spending, such as the Social Expenditure Database (SOCX), are quite established and regularly updated by relevant offices in each country and international organization (e.g., OECD)(Castles, 2002).

The social spending as a percentage GDP provided by the KOSIS, which is also reported to the OECD, consists of nine policy areas, such as old age, survivors, incapacity-related benefits, health, family, active labor market policies, unemployment, housing, and other social policy areas. It should be noted that not only public social expenditure but also mandatory private social expenditure are also included in the data. Arguably, using these social expenditure data are one of the established ways of measuring the welfare expansion of a state.

Income inequality has been measured with the Gini coefficient of households with two or more members living in cities, which is a widely used and quite established way of measuring inequality ${ }^{14}$. It should be noted that the higher the Gini coefficient is, the more unequal the distribution of income in a society is. For instance, a state with a Gini coefficient of 1 is regarded as one with perfect inequality, while a state with Gini coefficient 0 is regarded as one with perfect equality.

To measure poverty, the poverty rate has been used. The poverty rate is the ratio of the number of households with two or more members living in cites whose income falls below the poverty line (taken as half the median household income of the total population). This way of measuring poverty has been most widely used by many countries and adopted by the OECD as an official indicator of poverty.

The partisanship of the government, which is one of the independent variables, is measured simply as a dummy variable $(1=$ progressive parties, $0=$ conservative parties $)$ for the regression analysis. Actually, the progressivism of a party (or a government) is a contentious issue, making it difficult to measure the extent of. Furthermore, as in the case of South Korea, if a party's electoral basis is closer to regional one, rather than a certain sector of the electorates such as workers, it would be likely that the party maintains ambiguous attitudes towards redistribution or welfare. However, given all the electoral basis issues, it is quite clear that South Korea has two major parties, one of which has been regarded as conservative in general, the other of which has been regarded as progressive compared with its major competitor. Even though the conservative party occasionally shows progressive attitudes towards welfare, it has never been regarded as having its political identity converted to a

14 In South Korea, comparatively accurate information about household income, which is used to calculate the Gini coefficient and poverty rate, is usually collected from the Urban Family Income and Expenditure Survey (Hong \& Song, 2006) 
progressive identity. Undoubtedly, there are two groups of political parties with traditionally different identities in terms of political progressivism in South Korea.

The partisanship of the parliament has been measured with the proportion of MPs from a major progressive party. Even though South Korea's political system is not a parliamentary system but a presidential system with relatively more power given to the president when compared with other democratic states, the parliament has usually been regarded as an important player in the control and balance of entire political powers.

Union membership has been measured with the percentage of salary workers organized into unions. It is expected that union membership is relatively stronger under progressive regimes, also contributing to an enhanced social protection system with increased social spending.

To measure political freedom, each year's score for the political freedom of South Korea has been used. As a US government-funded non-governmental organization, Freedom House provides a score of political freedom worldwide on a yearly basis. It is usually expected that states with more political freedom spend more on social protection.

In relation to socio-economic variables, the GDP growth rate, trade openness, unemployment rate and population aging are considered. The GDP growth rate is measured with the annual percentage of GDP growth, the data for which are provided by the World Bank. It is expected that increased GDP growth allows more funding for welfare policies, contributing to more social spending.

In terms of the relationship between globalization and welfare state, trade openness is measured with the ratio of trade to GDP. However, there has been a huge controversy over this relationship. There have been arguments that globalization puts downward pressure on social spending (Glatzer \& Rueschemeyer, 2005), in contrast to the counter arguments that globalization and the welfare state have mutually reinforcing relationships (Becker, 2011; Cameron, 1978; Katzenstein, 1985; Rieger \& Leibfried, 2003; Walter, 2010). Given the empirical evidence of the latter type of argument (Kersbergen \& Vis, 2014), it is expected that more trade openness leads to more social spending.

Unemployment is usually regarded as the cause of increased social spending. The annual percentage of unemployment is used as data measuring unemployment. It is expected that a high unemployment rate leads to more spending of unemployment benefits. However, unemployment benefits could be a target of retrenchment due to a lack of acceptance by the public about people who are unemployment beneficiaries (Kersbergen \& Vis, 2014, p. 86).

Given that South Korea is one of the countries seriously suffering from low fertility rates and aging problems, population aging is clearly expected to contribute to increased social spending. It is especially notable that this study uses data not from two different regimes of the same period but from two different regimes of different periods (these regimes were in power for almost the same length of time, however), which means that the examination shows undoubtedly distinct differences between the two regimes because the regimes of the later period certainly suffered more from population aging. 


\section{Empirical Results}
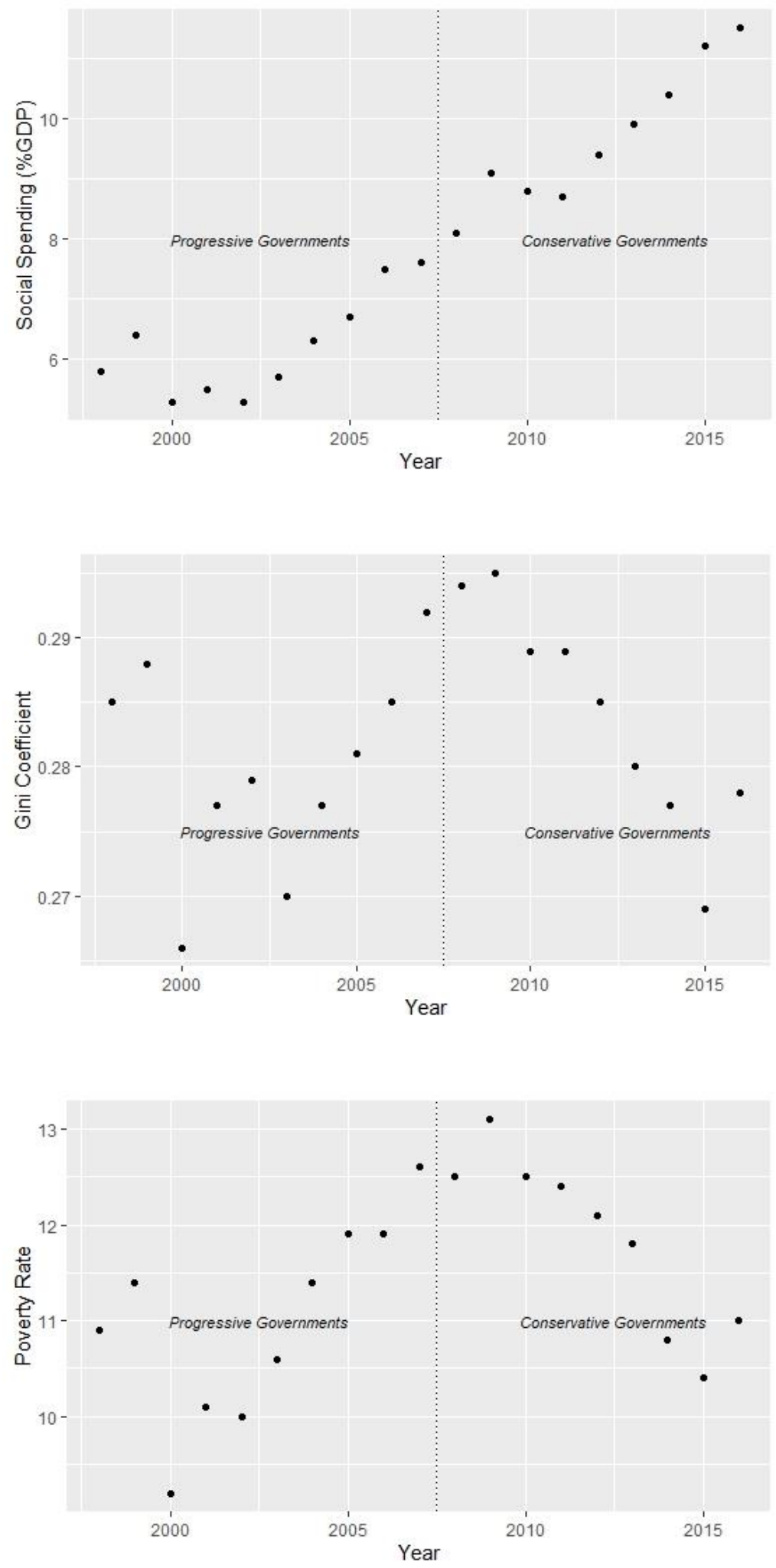

Figure 3. Scatterplots of Social Spending, Income Inequality, and Poverty Rate in 1998-2016 
Source: KOSIS (n.d.)
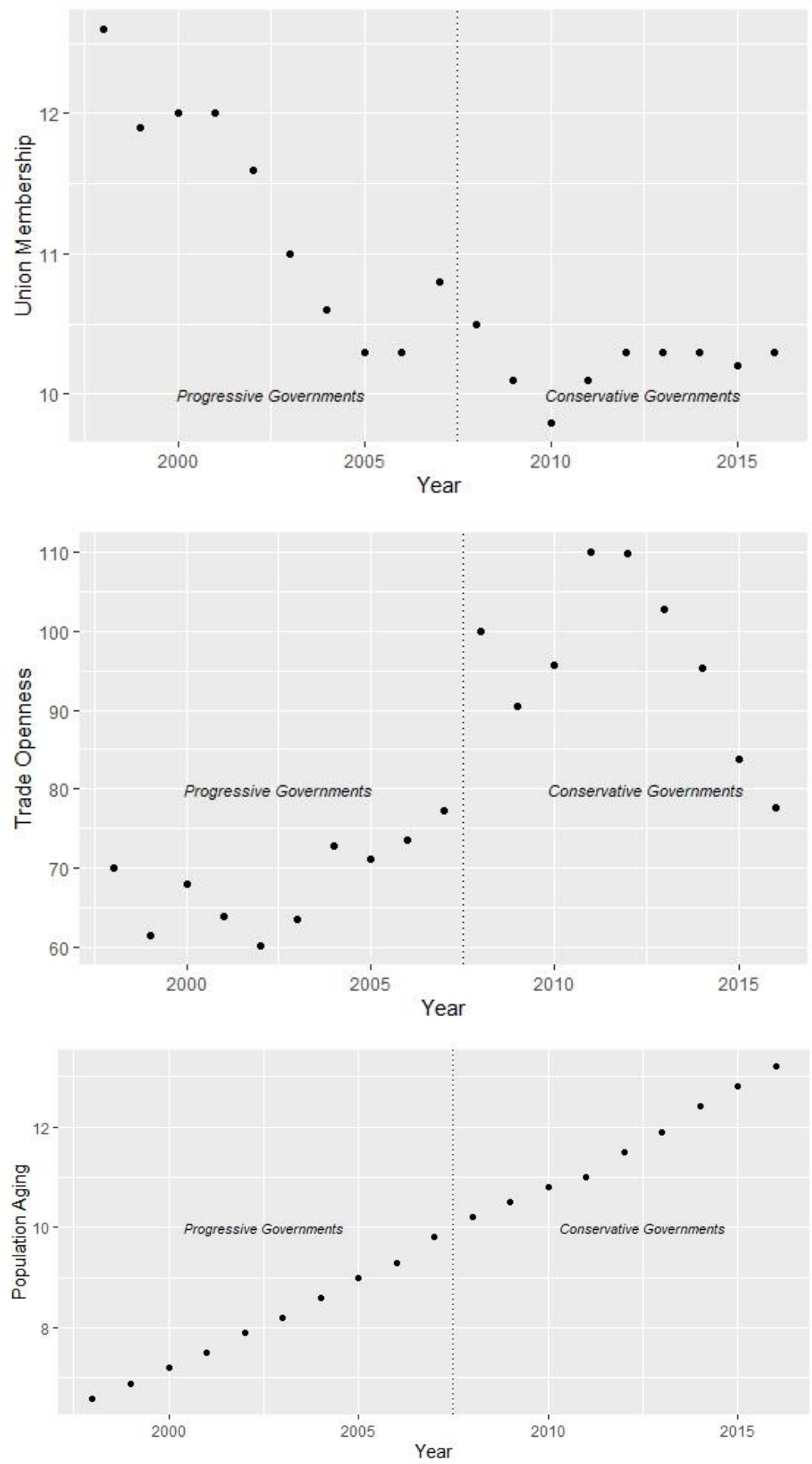

Figure 4. Scatterplots of Union membership, Trade Openness, and Population Aging in 1998-2016

Source: KOSIS (n.d.) 

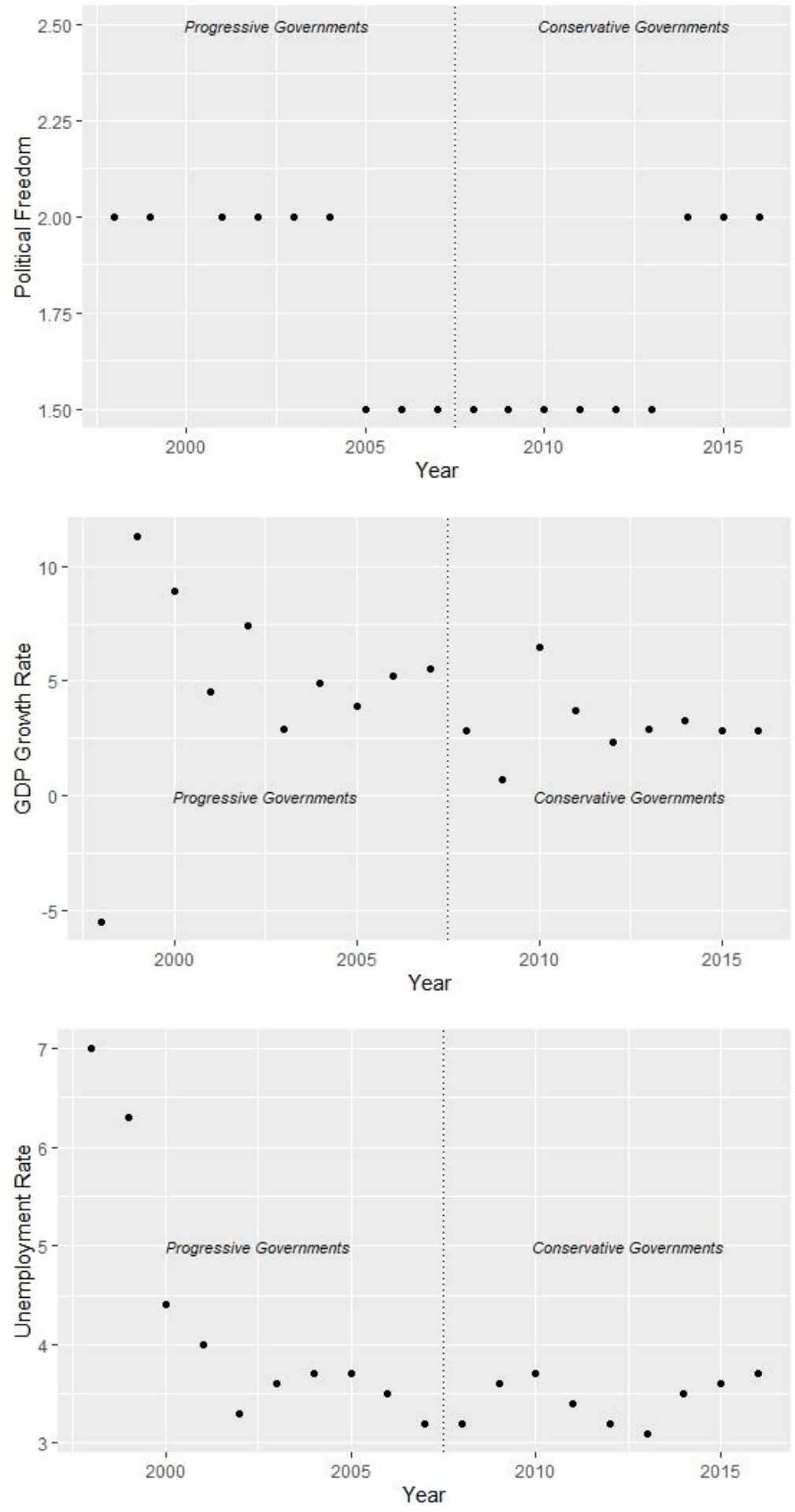


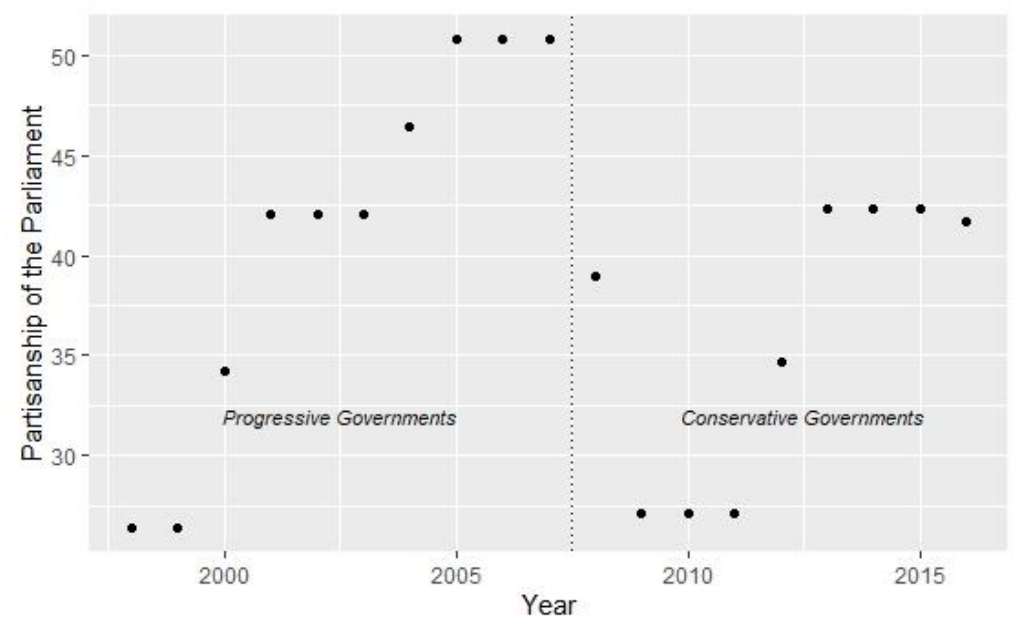

Figure 5. Scatterplots of Political Freedom, GDP Growth Rate, Unemployment Rate, and Partisanship of Parliament in 1998-2016

Source: KOSIS, Freedom House, World Bank, and National Assembly (n.d.)

Table 3. ANOVA Results

\begin{tabular}{l|l|l}
\hline Significant differences & Social spending & $\begin{array}{l}\text { Union membership } \\
\text { Trade openness } \\
\text { Population aging }\end{array}$ \\
\hline No significant differences & Income inequality & $\begin{array}{l}\text { Political freedom } \\
\text { GDP growth rate } \\
\text { Unemployment rate }\end{array}$ \\
& Poverty & Partisanship of Parliament
\end{tabular}

$($ Alpha $=0.05)$

\begin{tabular}{|c|c|c|c|c|c|c|}
\hline \multicolumn{7}{|c|}{ ANOVA } \\
\hline \multirow{4}{*}{$\begin{array}{l}\text { Social Spending (\% } \\
\text { GDP) }\end{array}$} & \multirow{4}{*}{$\begin{array}{l}\text { Between Groups } \\
\text { Within Groups }\end{array}$} & Sum of Squares & $\mathrm{df}$ & Mean Square & \multirow[t]{2}{*}{$\mathrm{F}$} & \multirow{2}{*}{$\begin{array}{r}\text { Sig. } \\
.000\end{array}$} \\
\hline & & 56.96 & 1 & 56.96 & & \\
\hline & & 17.30 & 17 & 1.02 & & \\
\hline & & & \multicolumn{4}{|c|}{ Alpha $=0.05, \mathrm{~F}($ critical $)=4.45, \mathbf{F}($ obtained $)=\mathbf{5 5 . 9 6}$} \\
\hline \multirow{3}{*}{ Income Inequality } & Between Groups & .000 & 1 & .000 & $1 . .099$ & .309 \\
\hline & Within Groups & .001 & 17 & .000 & & \\
\hline & & & \multicolumn{4}{|c|}{ Alpha $=0.05, \mathrm{~F}($ critical $)=4.45, \mathrm{~F}($ obtained $)=1.099$} \\
\hline \multirow{3}{*}{ Poverty Rate } & Between Groups & 3.378 & 1 & 3.378 & 3.497 & .079 \\
\hline & Within Groups & 16.422 & 17 & 0.966 & & \\
\hline & & & \multicolumn{4}{|c|}{ Alpha $=0.05, \mathrm{~F}($ critical $)=4.45, \mathrm{~F}($ obtained $)=3.497$} \\
\hline Union Membership & Between Groups & 5.720 & 1 & 5.720 & 15.54 & .001 \\
\hline
\end{tabular}




\begin{tabular}{|c|c|c|c|c|c|c|}
\hline & Within Groups & 6.258 & 17 & 0.368 & & \\
\hline & & & \multicolumn{4}{|c|}{ Alpha $=0.05, \mathrm{~F}($ critical $)=4.45, \mathbf{F}($ obtained $)=\mathbf{1 5 . 5 4}$} \\
\hline \multirow{3}{*}{ Trade Openness } & Between Groups & 3713 & 1 & 3713 & 49.93 & .000 \\
\hline & Within Groups & 1264 & 17 & 74 & & \\
\hline & & & \multicolumn{4}{|c|}{ Alpha $=0.05, \mathrm{~F}($ critical $)=4.45, \mathbf{F}($ obtained $)=\mathbf{4 9 . 9 3}$} \\
\hline \multirow{3}{*}{ Population Aging } & Between Groups & 57.66 & 1 & 57.66 & 51.03 & .000 \\
\hline & Within Groups & 19.21 & 17 & 1.13 & & \\
\hline & & & \multicolumn{4}{|c|}{ Alpha $=0.05, \mathrm{~F}($ critical $)=4.45, \mathbf{F}($ obtained $)=\mathbf{5 1 . 0 3}$} \\
\hline \multirow{3}{*}{ Political Freedom } & Between Groups & .125 & 1 & .125 & 2 & .176 \\
\hline & Within Groups & 1.000 & 16 & .063 & & \\
\hline & & & \multicolumn{4}{|c|}{ Alpha $=0.05, \mathrm{~F}($ critical $)=4.49, \mathrm{~F}($ obtained $)=2$} \\
\hline \multirow{3}{*}{ GDP Growth Rate } & Between Groups & 15.54 & 1 & 15.54 & 1.35 & .261 \\
\hline & Within Groups & 195.65 & 17 & 11.51 & & \\
\hline & & & \multicolumn{4}{|c|}{ Alpha $=0.05, \mathrm{~F}($ critical $)=4.45, \mathrm{~F}($ obtained $)=2$} \\
\hline \multirow{3}{*}{ Unemployment Rate } & Between Groups & 3.228 & 1 & 3.228 & 3.46 & .080 \\
\hline & Within Groups & 15.863 & 17 & .933 & & \\
\hline & & & \multicolumn{4}{|c|}{ Alpha $=0.05, \mathrm{~F}($ critical $)=4.45, \mathrm{~F}($ obtained $)=3.46$} \\
\hline \multirow{3}{*}{$\begin{array}{l}\text { Partisanship of } \\
\text { Parliament }\end{array}$} & Between Groups & 131.8 & 1 & 131.83 & 1.88 & .188 \\
\hline & Within Groups & 1191.8 & 17 & 70.11 & & \\
\hline & & & \multicolumn{4}{|c|}{ Alpha $=0.05, \mathrm{~F}($ critical $)=4.45, \mathrm{~F}($ obtained $)=1.88$} \\
\hline
\end{tabular}

As a starting point, it is necessary to determine whether there has been a significant difference in social spending between the two groups of regimes. Not surprisingly, the ANOVA results revealed statistically significant differences in social spending (\% GDP) between these two groups. Based on ANOVA comparing progressive regimes with conservative regimes in terms of social spending as a percentage of GDP, it is clear that the level of social spending has been significantly different between the two groups of political regimes. Additionally, from the scatterplots below, it can be seen that social spending has been growing steadily under both groups of political regimes in South Korea. Does this result justify the argument that conservative governments are more likely to increase social spending to enhance social protection in general? To answer this question, the other factors beyond the regimes that could explain the difference in social spending between these two political groups should be examined.

It should also be noted that the differences in the Gini coefficient and poverty rate of different political regimes are not statistically significant. Based on the finding that the level of social spending has clearly been higher under conservative regimes than under progressive regimes, it could be expected that the level of income inequality and the poverty rate were much lower under the conservative regimes due to the increased level of spending. However, ANOVA comparing both political groups in terms of the Gini coefficient and poverty rates reveals no significant difference based on political regime. ${ }^{15}$

15 This does not mean that social spending increased by the conservative regimes did not lead to the reduction of income inequality or the poverty rate in South Korea. ANOVA just tells us 


\section{\لMacrothink}

From the results above, some questions arise. First, why did the increased level of social spending lead to the no significant reduction of income inequality and poverty? Second, what kind of political and socioeconomic factors affected the level of social spending by each regime?

The differences in union membership between the different political regimes are statistically significant. It is usually expected that increased union membership leads to increased social spending, also contributing to the reduction of income inequality and the poverty rate. As seen below, the union membership, measured as the percentage of salary workers organized into unions, has been steadily decreasing, as the political regimes have moved from progressive to conservative regimes. Given that this factor has a distinct pattern during the targeted period of this study, it could be added to the regression equation to examine how much this variable, combined with other variables, affected social spending.

The differences in trade openness between different political regimes are statistically significant. Trade openness measured as the ratio of trade to GDP has been steadily increasing throughout the targeted period of this study (except for a few outliers during the Park Geun-hye regime). This clear pattern would make it meaningful to add this variable to the regression equation to evaluate how much of an effect this variable-compared with other variables - would have on social spending, income inequality and poverty.

The differences in population aging between different political regimes are statistically significant. As the variable with the clearest pattern of increasing throughout the targeted period of this study, population aging is one of the major candidates believed to have contributed to the increased social spending. If this variable were added to the regression equation, it would reveal how much population aging, compared with other variables, affected social spending.

The differences in political freedom between different political regimes are NOT statistically significant. The differences in the GDP growth rate between different political regimes are NOT statistically significant. The differences in the unemployment rate of different political regimes are NOT statistically significant. The differences in the partisanship of the parliaments of different political regimes are NOT statistically significant.

\subsection{Modified Regression Equations}

In accordance with the ANOVA results illustrated above, the initial equations could be modified as follows, including only the variables with statistically significant differences between the two groups of political regimes. This simplified design for the equation is necessary, given the limited number of samples spanning a period of less than 20 years.

\subsubsection{Modified Model 1}

Social spending $=\mathrm{a}+\mathrm{b} 1$ Partisanship of the government $+\mathrm{b} 2$ Union membership +

that Gini coefficient and poverty rates are not different between two political regimes. 
b3 Trade openness + b4 Population aging $+e$
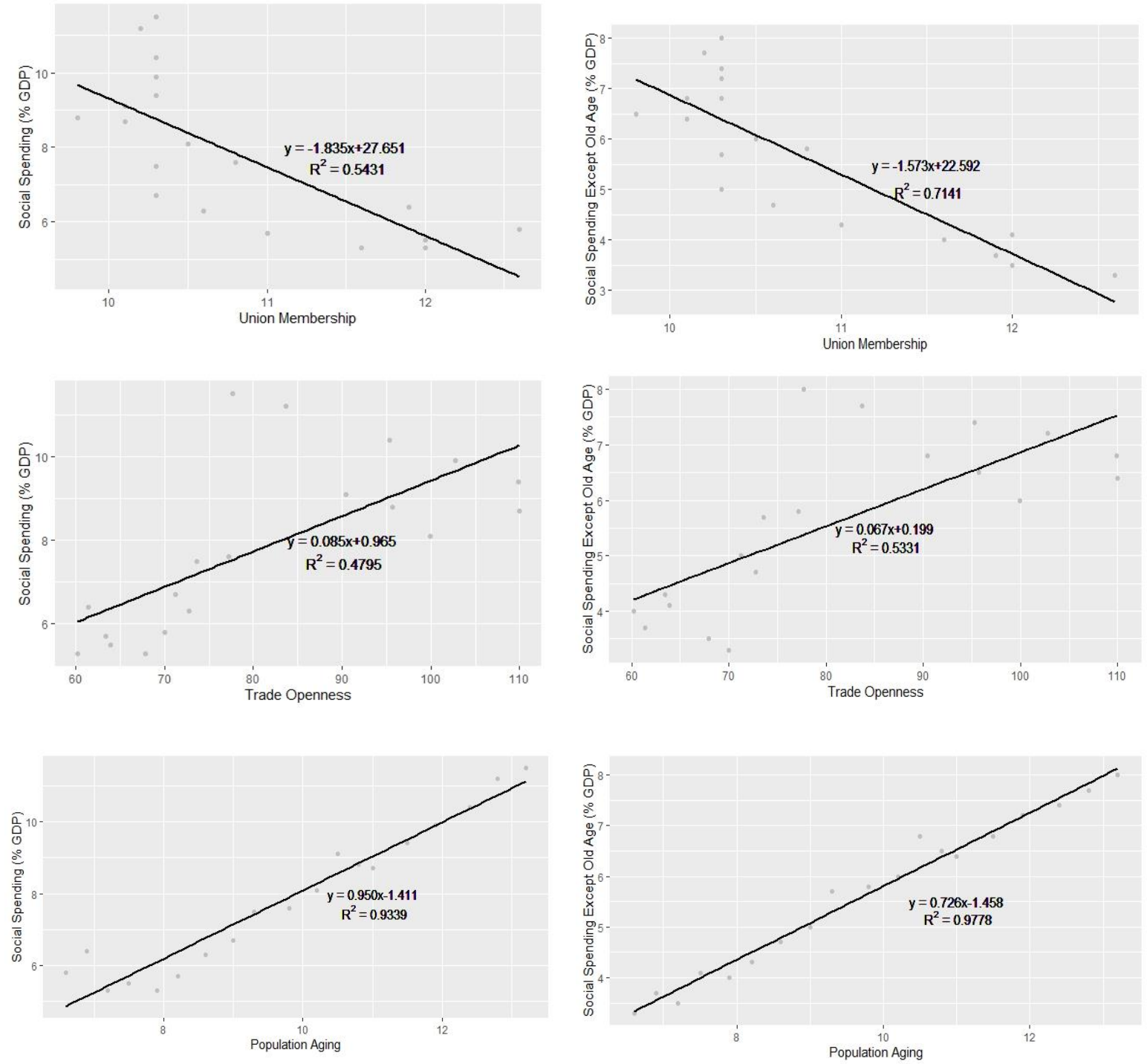

Figure 6. The Relationship between Social Spending (with or without Old Age, \% GDP) and Union Membership, Trade Openness, and Population Aging

Source: KOSIS (n.d.) 


\subsubsection{Empirical results of modified model 1}

Table 4. Linear Regression Output Specifying the Relationship between Union Membership, Trade Openness, Population Aging and Social Expenditure

\begin{tabular}{l|cccc}
\hline Model & Coefficients & Standard Error & $\mathrm{t}$ & Sig \\
\hline Constant & -2.843 & 5.027 & -0.565 & 0.581 \\
$\begin{array}{l}\text { Partisanship of } \\
\text { the Government }\end{array}$ & -1.013 & 0.675 & -1.501 & 0.156 \\
Union & 0.318 & 0.278 & 1.145 & 0.272 \\
Membership & -0.014 & 0.015 & -0.927 & 0.370 \\
Trade Openness & 0.919 & 0.154 & 5.934 & 0.000 \\
Population & & & R-square $=0.952$, Adjusted $\mathrm{R}^{2}=0.938$ \\
Aging & & & \multicolumn{2}{c}{} \\
\hline
\end{tabular}

Dependent variable $=$ Social Spending $(\%$ GDP $)$

The model summary tells us that the independent variables are strongly associated with social spending (\% GDP). The coefficient of determination "R square" is 0.938 . An R2 of 0.938 means that the independent variables jointly explain $94 \%$ of the variation in social spending as a percentage of GDP. The partisanship of the government does not have statistically significant effects. The p-values are greater than 0.05 in tables 4 (see also Table 5). That means that the partisanship of the government is not statistically related with increasing social spending. From the regression results above, it was confirmed that "population aging"- among the variables with significant differences between the two groups of political regimes - was the most important factor contributing to the increase in social spending in general. It was not confirmed that conservative governments contributed more to the increase in social spending than progressive governments did.

Given that South Korea belongs to the group of countries with extremely aging societies, it could be expected that population aging explains a large part of the increased social spending. Therefore, it would be worth examining whether increased social spending WITHOUT old age-related expenditures (the statistical category labeled as old age) can also be explained by population aging. Contrary to the case of social spending, including old age-related expenditures, it is not readily expected that population aging contributes to increases in social spending outside the old age category. To test the strength of population aging in explaining the increase in social spending outside of for old age expenditures, the multiple regression design could be modified further as follows. Under this second multiple regression design, the dependent variable is social spending without old age expenditures; however, the same independent variables from the first regression design are taken into account.

\subsubsection{Modified Model 2}

Social Spending except Old Age $=a+b 1$ Partisanship of the government $+b 2$ Union membership $+\mathrm{b} 3$ Trade openness $+\mathrm{b} 4$ Population aging $+e$ 
Table 5. Linear Regression Output Specifying the Relationship Between Union Membership, Trade Openness, Population Aging and Social Spending (except Old Age)

\begin{tabular}{l|cccc}
\hline Model & Coefficients & Standard Error & $\mathrm{t}$ & $\mathrm{Sig}$ \\
\hline $\begin{array}{l}\text { Constant } \\
\text { Partisanship of }\end{array}$ & 2.273 & 2.302 & 0.987 & 0.340 \\
the Government & -0.259 & 0.309 & -0.836 & 0.417 \\
$\begin{array}{l}\text { Union } \\
\text { Membership }\end{array}$ & -0.213 & 0.127 & -1.674 & 0.116 \\
$\begin{array}{l}\text { Trade Openness } \\
\text { Population }\end{array}$ & -0.003 & 0.007 & -0.441 & 0.666 \\
$\begin{array}{l}\text { Aging } \\
\text { - }\end{array}$ & & 0.071 & 8.743 & 0.000 \\
\end{tabular}

Dependent variable $=$ Social Spending except Old Age $(\%$ GDP $)$

In relation to social expenditure except old age, population aging is not as strongly associated as in the first regression result, but it is still significantly associated, as confirmed by the second multiple regression results above. Figure 6 also shows similar regression lines with or without old age expenditures in the dependent variable.

To summarize, political actors (governments) had little effect in terms of the increase in social spending in South Korea from 1998 to 2016. The most distinguished factor leading to the increase in social spending among the variables with significant differences between the two groups of political regimes was population aging. It was also confirmed that income inequality and poverty rate were not significantly different between the two groups of political regimes. It was population aging that significantly increased the GDP ratio of social spending, no matter how each regime argued they were keen on welfare expansion to resolve income inequality and poverty problems. In the case of the South Korean welfare state, especially, in regard to the period from 1998 to 2016, actor-focused theory can be rejected by the empirical results of this study.

\section{Aging Society and Path Dependence}

As empirically confirmed above, in South Korea, under conservative regimes, there was more social spending. However, increased social spending was fundamentally due to population aging, and there was no significant difference in income inequality and poverty between political regimes. In other words, increased social spending has not been the result of any strong political actors' will but rather a natural phenomenon as the population ages. Even with competitive words and plans from political actors, from either progressive or conservative parties, in relation to welfare state, there have been no significant differences in poverty and income inequality, the reduction of which could be regarded as the aims of welfare policies. Clearly, social spending has increased as South Korea has become politically conservative, in contrast to our initial expectations; however, most of this spending increase has been explicable by the aging population. South Korean regimes have sometimes benefitted from populism related to the welfare state (e.g., winning the election) while being 
hesitant to move forward with any path-breaking welfare policies once in power. South Korea has been no exception in terms of the path-dependent nature of the welfare state(Pierson, 1994) .

\section{Conclusion and Policy Implications}

Even though South Korean politics resembles Western democracies in the sense that it has distinctive left and right actors (or parties), the patterns of social spending were not in line with what is normally expected in relation to the progressivism of political regimes. Rather than strictly abiding by their political beliefs, the political regimes in South Korea have taken practical attitudes towards the welfare state, arguably to win elections and achieve other political aims, based on the popularity of their governments. Governmental power in South Korea from 1998 to 2016 has been divided between two groups (progressive and conservative) of political regimes; the conservative group has taken either a pro-market attitude or approaches based on populism and definitely spent much more than its progressive counterparts have. However, positive trend of increasing social spending has been overshadowed by sustained income inequality and poverty during the last twenty years. In sum, as one of the fastest aging countries in the world, the South Korean welfare state will likely be more path-dependent in the future, suffering more from inequality and poverty problems, despite the state's heavy investment in welfare for the elderly. Therefore, what is needed to tackle inequality and poverty effectively is the enhancement of the redistributive policy processes, which can be maintained regardless of the political regimes in power.

As a country with hardly any experience of path-breaking reform in terms of the welfare state, South Korea will almost certainly have to face similar challenges to those other welfare states have had to deal with in the sense that any attempts to make fundamental and sustainable changes to the pre-existing framework of its welfare system will likely be met with strong opposition from various political parties and interest groups or the public in general, often carrying the risk of losing elections (Pierson, 1994). Given that electorates are more sensitive to losses than to gains(Kuhnen \& Knutson, 2005; Loewenstein et al., 2008; Pierson, 1994; Smith et al., 2002) and that any change in policies would almost certainly result in there being a losing side or sides, it might be tempting for policy makers to act only in a path-dependent manner. In the case of well-established welfare states, path dependence could be regarded as a protection against any attempts of retrenchment (Pierson, 1994); however, in the case of developing welfare states such as South Korea, path dependence could lead to heavy resistance against any kind of reform in relation to welfare expansion.

What has been common to all four of the most recent regimes in South Korea is the fact that welfare could no longer be regarded as a minor issue. Having noticed the growing concerns about social protection among the electorate, political actors have tried to design and implement their own plans. Conservative parties, traditionally regarded as market-oriented, were often successful in making themselves look like pro-welfare parties, even successfully winning elections. However, once they took political power, almost no path-breaking welfare policies were made by these regimes. The increase in social spending was rather due to natural phenomena such as aging or just the cost needed to maintain pre-existing welfare 
policies, many of which were designed by previous regimes (Lee, 2016) and contributed little to the reduction of income inequality and poverty. Progressive actors, conventionally regarded as pro-welfare parties, initially had to focus on social insurance-based approaches to resolve a variety of welfare issues, such as unemployment, under the conditions imposed by IMF. Towards the end of their regimes, a major plan of economic and welfare policies, which was titled 'Vision 2030'16 and included long-term strategies for the balanced development of the economy and social protection, was drafted, but it was never put into practice, due to the immediate power transition to a conservative regime that had its own plans and agenda.

However, the reason the conservative party was able to survive another presidential election in 2012 was its adoption of some of progressive welfare plans, part of which were even from Vision 2030. As a presidential candidate from the conservative side, Park Geun-hye's welfare plans were even regarded as quite similar to those of the Swedish welfare state (Joo, 2014). Contrary to her predecessor's welfare policies with targeted approaches that resulted in limited protection, Park Geun-hye focused on universal protection, covering almost the entire life cycle of an individual with a so-called lifelong social security package, which, again, was neglected due to Park's pursuit of the "division of interest groups rather than social integration" (Joo, 2014, p. 141) once she took political power.

As arguably confirmed in the Western context, social policy is regarded as one of the most resilient domestic policies (Pierson, 1994). Even though South Korea has had relatively limited experience with welfare state management, recent governments and presidential candidates have recognized that taking a certain approach with regard to welfare issues can make them win or lose votes, which has made most presidential candidates act like pro-welfare politicians, regardless of their background and that of their parties in relation to political progressivism. However, these pro-welfare manifestos and plans underwent many modifications or delayed processes of implementation for a number of reasons, such as conflict with interest groups or preoccupation with more urgent issues, which has confirmed the path-dependent nature of social policy in the context of South Korea.

From past experiences in South Korean politics, it is expected that future governments will find it hard to dismiss welfare policies. Furthermore, the traditional political beliefs of parties in terms of redistributive approaches can be compromised whenever necessary to win elections. South Korea has witnessed a conservative party radically adopt progressive welfare plans in order to maintain its political power and ditch them soon after being elected as the party in power. The country also witnessed a progressive party losing power and having almost no chance to implement the welfare policies it had drafted in accordance with its progressive beliefs.

Following a period with two conservative regimes, since 2017, South Korea has had a new government that shares political blood with president Roh Moo-hyun. With the beginning of a new politically progressive era, the government ambitiously drafted a brand-new social

16 This plan was made public in 2006. President Roh Moo-hyun's party lost the presidential election in 2007. 
protection plan with an emphasis on the universalism of the welfare state ${ }^{17}$. Similar to other welfare states, South Korea's social policies are not free from path dependence, and any welfare reform can hardly survive without sustainable political support. Given that political support from the public is unpredictable, as it always has been, policy makers have to be cautious about the design and implementation of their plans, being sure that they do not end up being simply political slogans.

\section{Acknowledgments}

An earlier draft of this paper was presented at the GSPA NIDA 2018 International Conference, Bangkok, Thailand, on July 5, 2018. I thank all of the participants and scholars who provided me valuable comments at the conference.

\section{References}

Allan, J. P., \& Scruggs, L. (2004). Political partisanship and welfare state reform in advanced industrial societies. American Journal of Political Science. https://doi.org/10.1111/j.0092-5853.2004.00083.x

Becker, U. (ed. . (2011). The changing Political Economies of Small West European Countries. Amsterdam: Amsterdam University Press. https://doi.org/10.26530/OAPEN_391373

Bonoli, G. (2007). Time matters: Postindustrialization, new social risks, and welfare state adaptation in advanced industrial democracies. Comparative Political Studies. https://doi.org/10.1177/0010414005285755

Brown, D. S., \& Hunter, W. (1999). Democracy and Social Spending in Latin America, 1980-92. American Political Science Review. https://doi.org/10.2307/2586112

Buracom, P. (2011). The Determinants and Distributional Effects of Public Education, Health, and Welfare Spending in Thailand. Asian Affairs: An American Review, 38(3), 113-142. https://doi.org/10.1080/00927678.2011.565282

Cameron, D. R. (1978). The Expansion of the Public Economy: A Comparative Analysis. American Political Science Review. https://doi.org/10.2307/1954537

Castles, F. G. (1982). The Impact of Parties: Politics and Policies in Democratic Capitalist States. (F. G. Castles, Ed.). London; Beverly Hills, Calif.: Sage Publications.

Castles, F. G. (1998). Comparative Public Policy. Cheltenham: Edward Elgar.

Castles, F. G. (2002). Developing new measures of welfare state change and reform. European Journal of Political Research. https://doi.org/10.1111/1475-6765.00024

De Schweinitz, K. (1964). Industrialization and democracy: economic necessities and political possibilities. Free Press of Glencoe.

17 The National Social Protection Plan (2019-2023) was made public in February 2019. 
Dornbusch, R., \& Edwards, S. (1991). "The macroeconomics of populism." The macroeconomics of populism in Latin America. University of Chicago Press. https://doi.org/10.7208/chicago/9780226158488.001.0001

Esping-Andersen, G. (1990). The three worlds of welfare capitalism. In The three worlds of welfare capitalism. Cambridge \& Princeton, NJ: Polity \& Princeton University Press. https://doi.org/10.2307/2073705

Geddes, B. (1995). The politics of economic liberalization. Latin American Research Review.

Glatzer, M., \& Rueschemeyer, D. (2005). Politics Matters. Globalization and Future of the Welfare State. https://doi.org/10.2307/j.ctt9qh56b

Haggard, Stephan, \& Kaufman, R. R. (2008). Development, Democracy, and Welfare States: Latin America, East Asia, and Eastern Europe. Princeton University Press. https://doi.org/10.1515/9780691214153

Haggard, Stephen, \& Kaufman, R. (1992). "The politics of economic adjustment." International Constraints, Distributive Conflicts and the State. Princeton, NJ: Princeton University Press. https://doi.org/10.1515/9780691188034

Haggard, Stephen, \& Kaufman, R. R. (1995). The Political Economy of Democratic Transitions. Princeton, NJ: Princeton University Press. https://doi.org/10.1515/9780691188010

Hibbs, D. A. (1977). Partisan theory after fifteen years. European Journal of Political Economy, 8(3), 361-373. https://doi.org/10.1016/0176-2680(92)90001-W

Hong, K. (1999). Korean welfare regime: the structure of the state-market-community relationship. Seoul: Nanam Press (in Korean).

Hong, K. Z., \& Song, H. K. (2006). Continuity and change in the Korean welfare regime. Journal of Social Policy. https://doi.org/10.1017/S0047279405009517

Huber, E., \& Stephens, J. D. (2001). Development and Crisis of the Welfare State: Parties and Policies in Global Markets. Chicago: University of Chicago Press. https://doi.org/10.7208/chicago/9780226356495.001.0001

Joo, E. (2008). A New Era in Korean Welfare Development: Proliferation of Welfare Market. Seosuk Social Science Chosun Univ., 1(2), 113-133.

Joo, E. (2014). Social Welfare Policy of Parkkeunhye Government and the Swedish Welfare Model under Changes. Scandinavia Research, (15), 103-142.

Kam, J. (1989). The development of state welfare and the role of working class parties. Korean Journal of Social Welfare Studies, 1(0), 117-136 (in Korean).

Kang, B. (2013). Welfare Politics by Korean Parties (in Korean) (Seminar Paper).

Katzenstein, P. J. (1985). Small states in World Markets: Industrial Policy in Europe. Ithaca, NY: Cornell University Press. 


\section{Macrothink}

Journal of Public Administration and Governance ISSN 2161-7104 2020, Vol. 10, No. 3

Kersbergen, K. Van, \& Vis, B. (2014). Comparative Welfare State Politics: Development, Opportunities, and Reform. Cambridge: Cambridge University Press. https://doi.org/10.15855/swp.2012.39.3.117

Kim, K., \& Kim, S. (2012). Quantitative Welfare Expansion and Systemic Retrenchment: an evaluation of welfare policy in the MB administration. Social Welfare Policy, 39(3), 117-49(in Korean).

Kim, Y. (2009). Social Investment and the Future of Social Policy in Korea. Seoul: Nanam Press (in Korean).

Korpi, W. (2006). Power Resources and Employer-Centered Approaches in Explanations of Welfare States and Varieties of Capitalism: Protagonists, Consenters, and Antagonists. World Politics. https://doi.org/10.1353/wp.2006.0026

Kuhnen, C. M., \& Knutson, B. (2005). The neural basis of financial risk taking. Neuron. https://doi.org/10.1016/j.neuron.2005.08.008

Lee, J. (2016). The Alteration of Welfare Policy According to the Government Change in South Korea (in Korean). Korea and International Politics, 32(2), 103-136.

Loewenstein, George, Rick, S., \& Cohen, J. D. (2008). Neuroeconomics. Annual Review of Psychology, 59, 647-672. https://doi.org/10.1146/annurev.psych.59.103006.093710

Ma, I. (2012). Political Parties' Welfare Policies and Election in South Korea (in Korean). In K. W. S. Society (Ed.), Politics and Economics in Korean Welfare State (pp. 251-461). Seoul: A-yeon.

Malloy, J. M. (1987). "The politics of transition in Latin America." Authoritarians and Democrats: Regime Transition in Latin America.

Nelson, Joan M., E. (1990). Economic crisis and policy choice: The politics of adjustment in the Third World. NJ: Princeton University Press. https://doi.org/10.1017/CBO9780511805288

Pierson, P. (1994). Dismantling the Welfare State? Reagan, Thatcher, and the Politics of Retrenchment. Cambridge: Cambridge University Press.

Pierson, P. (1996). The New Politics of the Welfare State. World Politics. https://doi.org/10.1353/wp.1996.0004

Pierson, P. (1998). Irresistible forces, immovable objects: Post-industrial welfare states confront permanent austerity. Journal of European Public Policy. https://doi.org/10.1080/13501769880000011

Pierson, P. (2011). The welfare state over the very long run. ZeS-Arbeitspapier.

Powell, M., \& Kim, K. T. (2014). The "Chameleon" Korean welfare regime. Social Policy and Administration. https://doi.org/10.1111/spol.12088

Przeworski, A., \& Limongi, F. (1993). Political Regimes and Economic Growth. Journal of Economic Perspectives. https://doi.org/10.1257/jep.7.3.51 


\section{Macrothink}

Journal of Public Administration and Governance ISSN 2161-7104 2020, Vol. 10, No. 3

Remmer, K. L. (1986). The Politics of Economic Stabilization: IMF Standby Programs in Latin America, 1954-1984. Comparative Politics, 1-24. https://doi.org/10.2307/421778

Remmer, K. L. (1990). Democracy and Economic Crisis: The Latin American Experience. World Politics, 315-335. https://doi.org/10.1017/S0043887100009138

Rieger, E., \& Leibfried, S. (2003). Limits to Globalization. Cambridge: Polity Press.

Ross, F. (2000). "Beyond left and right": The new partisan politics of welfare. Governance. https://doi.org/10.1111/0952-1895.00127

Schmidt, M. G. (2010). Parties. In The Oxford Handbook of The Welfare State. https://doi.org/10.1093/oxfordhb/9780199579396.003.0014

Seeleib-Kaiser, M., van Dyk, S., \& Roggenkamp, M. (2008). Party Politics and Social Welfare: Comparing Christian and Social Democracy in Austria, Germany, and the Netherlands. Cheltenham: Edward Elgar.

Skidmore, T. (1977). The Politics of Economic Stabilization in Postwar Latin America. Authoritarianism and Corporatism in Latin America.

Smith, K., Dickhaut, J., McCabe, K., \& Pardo, J. V. (2002). Neuronal substrates for choice under ambiguity, risk, gains, and losses. Management Science. https://doi.org/10.1287/mnsc.48.6.711.194

The unemployment rate reached 8.7\% (1999, April 17). Hankyoreh, p. 8.

Tsebelis, G. (1995). Decision Making in Political Systems Veto Players in Presidentialism, Parliamentarism, Multicameralism and Multipartyism. British Journal of Political Science. https://doi.org/10.1017/S0007123400007225

Walter, S. (2010). Globalization and the welfare state: Testing the microfoundations of the compensation hypothesis. International Studies Quarterly. https://doi.org/10.1111/j.1468-2478.2010.00593.x

Weaver, K. (2010). Paths and forks or chutes and ladders?: Negative feedbacks and policy regime change. Journal of Public Policy. https://doi.org/10.1017/S0143814X10000061

\section{Copyright Disclaimer}

Copyright for this article is retained by the author(s), with first publication rights granted to the journal.

This is an open-access article distributed under the terms and conditions of the Creative Commons Attribution license (http://creativecommons.org/licenses/by/4.0/). 